\section{Children's Literature Canon Comment}

The article about developing a canon of children's literature that appeared in the Summer 1980 Quarterly ended with a request for comments and suggestions. We have received both. Pat Pflieger, English Department, University of Minnesota had these questions:

First, why is Fungus the Bogeyman on the list? For his torical reasons? I have read the book and did not find it of much interest. Also, why is Edward Eager represented, but not Jane Langton, whose fantasies are of similar quality?

Deidre Ann Johnson shared Pat Pflieger's objection to Fungus; she says, "I cannot see any literary or historical value in the book." (My defense of the book is threefold: I like it, my five-year-old son likes it, and I think it marvellously evokes a strain of childlike behavior that rarely appears in children's books. I willingly admit that the first two of those reasons are utterly beside the point; but I stand by the third. On the other hand, I'd be willing to replace Fungus with either The Snowman or Father Christmas, or both.)

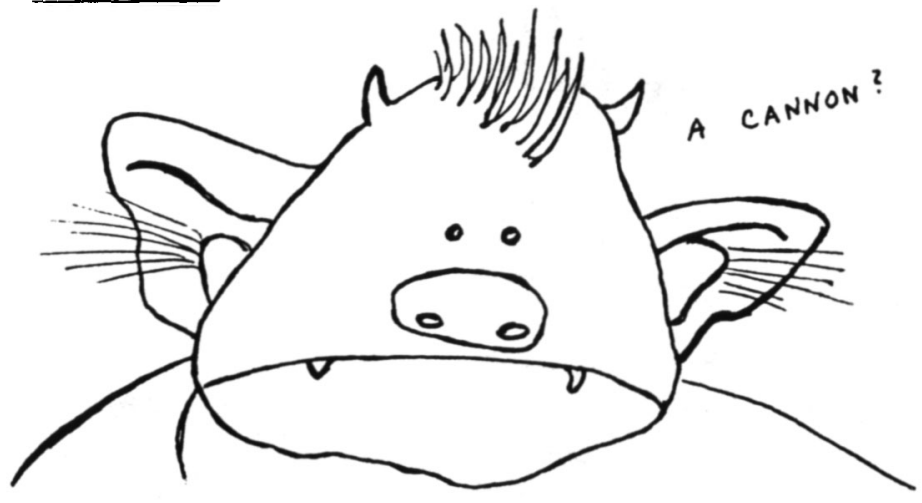

Adepted, with apologtee, from Raymand Briggn' Pungue the Bogermen.

Both Pflieger and Johnson suggested additions to the list. Pflieger's are mainly historical:

$H$ Jacob Abbott--the Rollo books

H Samuel Goodrich--the Peter Parley books

H Chapbooks--Guy of Warwicke, Tom Thumbe, etc.

$H$ Charles Kingsley--The Water-babies

$H$ Burnett--Little Lord Fauntleroy

H Maria Edgeworth--The Parent's Assistant, the Harry \& Lucy books

Catherine Sinclair--Holiday House

Jean Ingelow--Mopsa the Fairy

Johann Wyss--The Swiss Family Robinson

$H$ John Foxe--The Book of Martyrs
$H$ The Babee's Book and other medieval courtesy books

$H$ Madame de Genlis--Tales of the Castle Johnson's suggestions are more extensive:

Picture books

Alexander, Martha, various titles

Lenski, Lois, various titles

Brown, Margaret Wise, various titles

H Greene, Carla, career titles

Kellogg, Steven, various titles

Munari, Bruno, various titles

Vigna, Judith, various titles

Wells, Rosemary, various titles

H Wright, Dare, Lonely Doll series

Bright, Robert, Georgie series

Peet, Bill, various titles

Fantasy

Butterworth, 0liver, The Enormous Egg;

The Trouble with Jenny's Ear

Godden, Rumer, The Doll's House

Curry, Jane Louise, various titles

H Gruelle, Johnny, Raggedy Ann series

Packard, Edward, Choose Your Own Adventure series

McKillip, Patricia, Forgotten Beasts of Eld

Langton, Jane, Diamond in the Window

Nichols, Ruth, Walk Out of the World

$H$ Burgess, Thornton, various titles

Lampman, Evelyn, City Under the Back Steps

Uttley, Alison, Traveller in Time

Ormondroyd, Edward, Time at the Top

Heinlein, Robert, various titles

H Appleton, Victor, Tom Swift series

Appleton II, Victor, Tom Swift, Jr. series

Lang, Andrew, various titles

Wrightson, Patricia, Nargun and the Stars

Lagerlof, Selma, various titles

Norton, Andre, various titles

Realistic fiction

Snyder, Zilpha Keatley, various titles

Holland, Isabelle, Man Without a Face

Peck, Robert Newton, Soup

Peck, Richard, various titles

Blume, Judy, various titles (not just Margaret)

Robertson, Keith, Henry Reed series

Taylor, Sidney, All of a Kind Family series

Hentoff, Nat, I'm Really Dragged, But Nothing Gets Me Down

$H$ Lenski, Lois, Strawberry Girl

Donovan, John, I'11 Get There, It

Better Be Worth the Trip

Neville, Emily, It's Like This, Cat

Danziger, Paula, Can You Sue your Parents 
for Malpractice?

Lowry, Lois, various tities

Duncan, Lois, various titles

Cleary, Beverly, Henry Huggins series

Conford, Ellen, Dreams of Victory

$H$ Perkins, Lucy Fitch, Twins series

$H_{i}$ Hope, Laura Lee, Bobbsey Twins series

Warner, Gertrude, Boxcar Children (this

is too popular to omit)

Christopher, Matt, sports titles

Haywood, Caroline, Betsy series

Lovelace, Maud Hart, Betsy-Tacy series

Cavanna, Betty, various titles

duJardin, Rosamund, various titles

Kerr, M. E., Dinky Hocker Shoots Smack

Kerr, Judith, When Hitler Stole Pink

Rabbit

$H$ Porter, Gene Stratton, various titles

$H$ Fielding, Sarah, The Governess

$H$ Edgeworth, Maria

$H$ Trimmer, Sarah

$H$ chapbooks

(While I think many of these are excellent suggestions, I object to the vagueness of "various titles." In naming specific titles we force ourselves to make subtle but important critical distinctions.)

Ethel Heins, editor of Horn Book, made these comments:

Unanimity of opinion would be neither desirable nor possible, but I did find Perry Nodelman's

list a bit peculiar - as I'm

sure other people have also

done. Nevertheless, the pro-

ject itself is certainly

engaging -- and worthwhile.

Mrs. Heins offers for consideration some lists of her own: "Fifty Good Stories," "Fifty Good Picture Books," "Thirty Mid-Century Children's Books Every Adult Should Know," and "Fifty Children's Books Too Good to Miss." These and other lists may be ordered from The Horn Book Inc., Park Square Building, Boston MA 02116. I 1 ist here some titles which appear in Mrs. Heins ' lists that were not included in my tentative canon:

Anno. Anno's Alphabet.

Ardizzone. Little Tim and the Brave Sea Captain.

Briggs. Father Christmas.

Brown. Goodnight Moon.

Burton. Mike Mulligan and His Steam Shovel.

DuBois. Lion.
Graham. Harry the Dirty Dog.

Potter. The Tale of Tom Kitten.

Rey. Curious George.

Ungerer. The Three Robbers.

Waber. Ira Sleeps over.

Others

Byars, The Midnight Fox

Fleischman, By the Great Horn Spoon:

Fox, How Many Miles to Babylon?

Langton, The Diamond in the Window

Lively, The Ghost of Thomas Kempe

Snyder, The Headless Cupid

Haugaard, The Little Fishes

Hautzig, The Endless Steppe

Townsend, The Intruder

Westall, The Machine Gunners

Burch, Queenie Peavy

De Jong, The House of Sixty Fathers

Enright, Gone - Away Lake

Garner, Elidor

George, My Side of the Mountain

Godden, The Dolls House

Hamilton, Zeely

Stevenson, The Bushbabies

Serraillier, The Silver Sword

Sutcliff, Knight's Fee

Ullman, Banner in the Sky

Walsh, Fireweed

(Many of these are valuable suggestions. As a group they make clear a deficiency of my original list: not naming enough books that were first published in the fifties and early sixties. We tend to forget about books published much more than a decade ago unless they're continued to be immensely popular; and we tend to bypass earlier good books by writers who continue to publish.)

Eleanor Cameron, whose many children's books include The Court of the Stone Children and the recentiy published Beyond Silence, wrote of the difficulty of making lists:

What a searching of one's taste it takes, doesn't it? It's a confoundedly hard job, and I kept remembering, and reconsidering, and cutting and adding and putting back, and then considering for the fifth time, or the sixth. And when I compared my final list with yours, I was pleased to see how much we agreed. You had some there (like Scarry) that I wouldn't have thought of, and I send some titles to you that I hope you will consider.

These are additional titles Mrs.

Cameron suggests:

Bond, Nancy - A String in the Harp 
Briggs, K.M. - Hobberdy Dick

Byars, Betsy - The Summer of the Swans

Childress - A Hero Ain't Nuthin' But a Sandwich

Dickinson, Peter - The Dancing Bear

Eckert, Allen W. - Incident at Hawk's Hill

Eager, Edward - Knight's CastTe THalf Magic is a poor imitation of Nesbit, while Knight's Castle is truly excellent and funny and original. Please reconsider:)

Edmonds, walter D. - Drums Along the Mohawk; Bert Breen's Barn

Enright, Elizabeth - Gone-Away Lake (I can't resign myself to seeing you omit such a fine writer)

Erickson - A Toad for Tuesday

Farjeon, Eleanor - The Little Bookroom (Must, must!!!)

Fleischman, Sid - Humbug Mountain (He's master in his field)

Gardam, Jane - A Few Fair Days (A 1ittle gem); The Summer After the Funeral; A Long Way From verona. (Which to use? perhaps the first and last?) (She's a marvel!)

Hamilton, Virginia - The Planet of Junior Brown (Some will argue for Higgins, but I like this the better of the two.)

$H$ Irving - Rip Van Winkle and the Legend of Sleepy Hollow

Highwater, Jamake - An American Odyssey

James, Will - Smoky the Cowhorse

$H$ Jewett, Sarah Orne - The Country of the Pointed Firs

Lively, Penelope - The Ghost of Thomas Kempe; The House in Norham Gardens

(Lively can't possibiy be left out -

she's a top writer, and these two titles

are her best, along with Going Back, but

two are perhaps enough.)

London, Jack - The Call of the Wild

Mayne, William - A Game of Dark (A classic of its kind - High fantasy, or time fantasy, whichever you wish to call it.)

Peyton, K.M. - The Beethoven Medal; A Pattern of Roses (Wonderful time fantasy)

Richter, Conrad - The Light in the Forest

Sachs, Marilyn - The Bears' House

Sandburg - Rootabaga Stories

Singer, Isaac B. - The Fearsome Inn; Zlateh the Goat and other Stories

Steinbeck - The Long Valley; The Pearl

Uttley, Alison-A Traveler in Time

Wells, H.G. - The Time Machine

Wojciecohwska, Maia- Shadow of a Bull
I forgot:

Gates, Doris - Blue Willow

Kenda 11, Carol - The Gammage Cup

Krumgold, Joseph - ... and Now Miguel

Should there be more poetry re-

presented? And how about

Elizabeth Coatsworth?

Finally, a few comments of my own. Everyone who wrote suggested additions; and their suggested additions are all at least worth considering. But there was only one requested deletion. The enormity of the task confronting the canon committee is now clearer to me than it was before-it comes down to a simple matter of leaving things out. There are lots of good books; but how do we distinguish between the merely good ones and the very good ones, between the merely important and the essentially significant? I have no answer to those questions: furthermore, I am not particularly surprised that there are still some important books that nobody has got around to mentioning, including myself. How about Julia Cunningham's Dorp Dead? Dennis Lee's Alligator Pie? Ezra Jack Keats's Apartment Three? And so on, and so on.

\section{Perry Nodelman

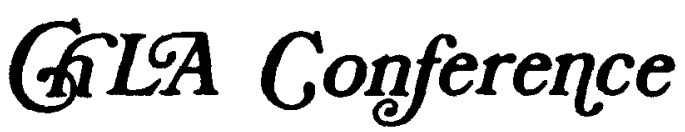

The Eighth Annual Conference of the Children's Literature Association will be held March 27-29, 1981 in Minneapolis. Featured speakers include Betsy Byars, Newbery Award winner, Karla Kuskin, winner of the 1979 NCTE Award for Poetry for Children, and noted critic, Zena Sutherland.

Also featured are discussion groups, panels and papers focused on the conference theme, Children's Books:From Creation to criticism.

The conference will be held at the Sheraton Ritz Hotel. Conference fees are as follows: $\$ 35.00$ for ChLA members (includes banquet); $\$ 20.00$ for Saturday and Sunday only; $\$ 15.00$ for student ChLA members; $\$ 50.00$ for Non-members (includes banquet and ChLA membership); $\$ 25.00$ for student non-member (includes banquet and membership.) The price of the theatre ticket and bus to the theatre is $\$ 5.75$. This is not included in conference fee.

Please make checks payable to CHLA. Send registration to Virginia Wolf, Dept. of English, University of Wisconsin-Stout, Aenomonie, WI 5475 ?. 